Physical Therapy Journal of Indonesia (PTJI) 2021, Volume 2, Number 1: 5-9

E-ISSN : 2722-6034 ; P-ISSN : 2722-0125

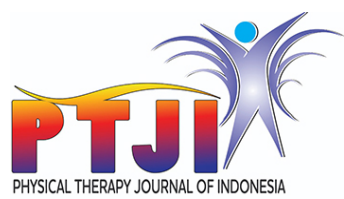

\title{
Ergonomic Intervention on Physical Therapy Programs Decrease Pain and Disability Level on Subject with Myogenic Low Back Pain: A Case Report
}

\author{
I Made Dhita Prianthara ${ }^{1 *}$, Ida Ayu Astiti Suadnyana ${ }^{1}$, Komang Tri Adi Suparwati ${ }^{1}$, \\ Siti Ainun Marufa ${ }^{2}$
}

\begin{abstract}
Introduction: Myogenic Low Back Pain is an uncomfortable pain on the lower back, often caused by musculoskeletal disorders resulting in pain and disability. This case report aims to review ergonomic intervention on physical therapy program on myogenic low back pain.

Case description: A 45-years-old man working as a roof tile craftsman complained of pain in the lower back area and already felt it for 1 month ago. The pain did not radiate to the leg. The patient has no neurological signs and symptoms. Patient-reported that he had experienced the same incident about 9 times in the last 3 years ago. The patient always performed bending motion and lifting the roof tile every day. The patient has been visited physical therapy and received ergonomic intervention and physical therapy

modalities for seven weeks. Following the ergonomic intervention and therapeutic exercise application, the Visual Analogue Scale score decreased from 6 to 0 . The Modified Oswestry Disability Index score gradually decreased from $60 \%$ disability to $0 \%$ disability. The patient no longer complained of MLBP and was able to lift the roof tile well.

Conclusion: After a seven-weeks physical therapy treatment session, the patient did not feel pain and can perform forward bending. Modified Oswestry Disability Index score improved and demonstrated improved lifting the roof tile without any complaints. We concluded that the ergonomic intervention combined with physical therapy programs effectively decreased pain and disability level on a subject with MLBP
\end{abstract} programs such as core stability exercise, soft tissue mobilization and

Keywords: ergonomic intervention, myogenic low back pain, physical therapy program

Cite this Article: Prianthara, I.M.D., Suadnyana, I.A.A., Suparwati, K.T.A., Marufa, S.A. 2021. Ergonomic Intervention on Physical Therapy Programs Decrease Pain and Disability Level on Subject with Myogenic Low Back Pain: A Case Report. Physical Therapy Journal of Indonesia 2(1): 5-9. D0l: 10.51559/ptji.v2i1.17

'Physical Therapy Department, Universitas Bali International, Bali, Indonesia

${ }^{2}$ Department of Physical Therapy, Faculty of Health Science, Universitas Muhammadiyah Malang, East Java, Indonesia

*Corresponding author: I Made Dhita Prianthara, Physical Therapy Department, Universitas Bali International, Bali, Indonesia; dhitaprianthara@gmail.com
Received : 2021-02-08 Accepted : 2021-04-24 Published: 2021-05-12

\section{INTRODUCTION}

Low Back Pain is the most common condition in society. Almost $80 \%$ of people in the world have experienced an episode of acute or chronic low back pain. The most common low back pain that often happens is myogenic low back pain (MLBP). ${ }^{1}$ MLBP is an uncomfortable pain in the lower back that is often caused by musculoskeletal disorders resulting in pain and disability. MLBP cause about $11 \%-12 \%$ of patients decreased functional activity and unable to do the job. In addition, MLBP also tends to recurrent about $26-37 \%$ that affects the decrease of work productivity. ${ }^{2}$

MLBP is often encountered in industry areas that are still using manual handling like roof tile craftsman. The workers usually doing forward bending motion and lifting and carrying the heavy loads, and work in fault body position that can increase the risk of MLBP. ${ }^{3}$ Lifting and carrying the heavy loads in fault position and done repetitively to be one factor why MLBP can develop on roof tile craftsman.
Darmasaba village is a central industry of roof tile in Bali Province, Indonesia. People in this village still use the traditional technique to make a roof tile without modern equipment. So, they still use human power and muscle when producing the roof tile. Working as a roof tile craftsman requires workers always to perform forward bending motion, lifting and carrying the heavy loads every day. A job with high physical stressors and fault body position can increase the risk of low back pain. ${ }^{3}$

Pain that arises usually comes from the protective mechanism of the body against injury. Nociceptors around the tissue injury will send signals to the spinal cord and forward signals to the brain, recognized as pain. Then the brain will send signals into the muscle to contract that aims to protect muscle in that area. Contraction of the muscle constantly occurs that will cause hypoxia and tissue damage which increased pain and disability. ${ }^{4}$

Evidence suggests that physical therapy programs can be applied to reduce symptoms caused by MLBP. 
But a physical therapist needs to advise patients to avoid severe injuries caused by work-related musculoskeletal disorders. Ergonomic intervention contains several ways or techniques that can be done when lifting and carrying loads with the right body posture. Ergonomic intervention can reduce musculoskeletal complaints felt by tile craftsmen by improving posture while working. The bending position causes the back muscles to work harder to maintain the body position. With the ergonomic intervention, it can improve the posture of tile craftsmen so that it can reduce pain. ${ }^{5}$

A previous review conducted showed that ergonomic intervention could reduce musculoskeletal complaints. ${ }^{6}$ Research by Pillastrini et al. also concluded that individual ergonomic intervention could improve work posture and reduce $\mathrm{LBP}^{5}$ However, several reviews of workplace interventions in computer users conclude that office-based ergonomic interventions have negative or detrimental effects on musculoskeletal health. ${ }^{7,8}$
There are no studies on ergonomic interventions in the workplace aimed at primary and secondary prevention of LBP symptoms. Given these gaps, it is necessary to conduct research to determine ergonomic interventions in reducing LBP complaints.

\section{CASE REPORT}

A 45-year-old man works as a roof tile craftsman in Darmasaba village. He complained of pain and cannot make bending motion since a month ago. He reported that he had experienced the same incident about nine times since three years ago. Pain appeared when he was lifting the roof tile. The pain was felt on the right and left side of the lower back, but the most perceived pain on the right side. There was no radiating pain to the leg or neurological sign and symptoms. Pain increases sharply when he sits in the long period when getting up from a seat, pain during forward-bending motion and back in the normal position so that the patient cannot perform

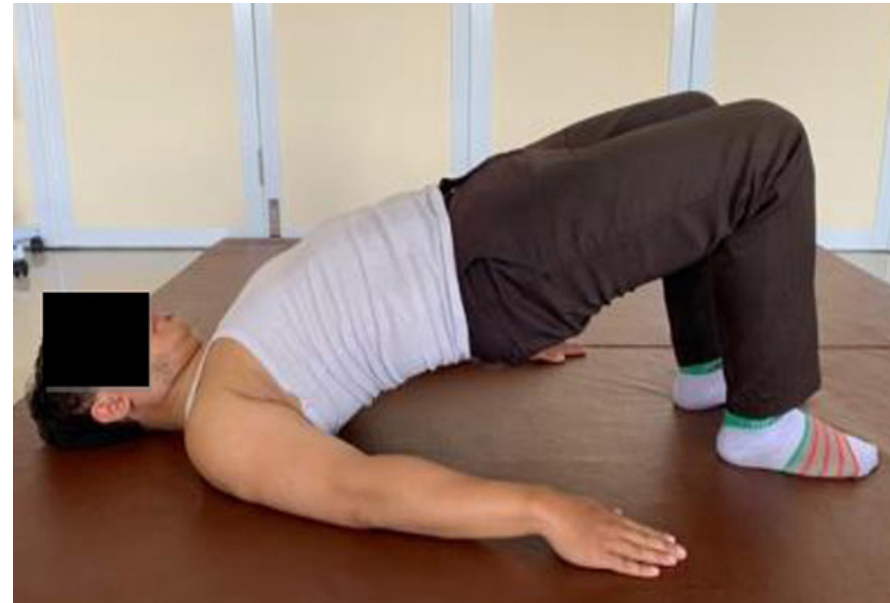

Figure 1. Bridging exercise

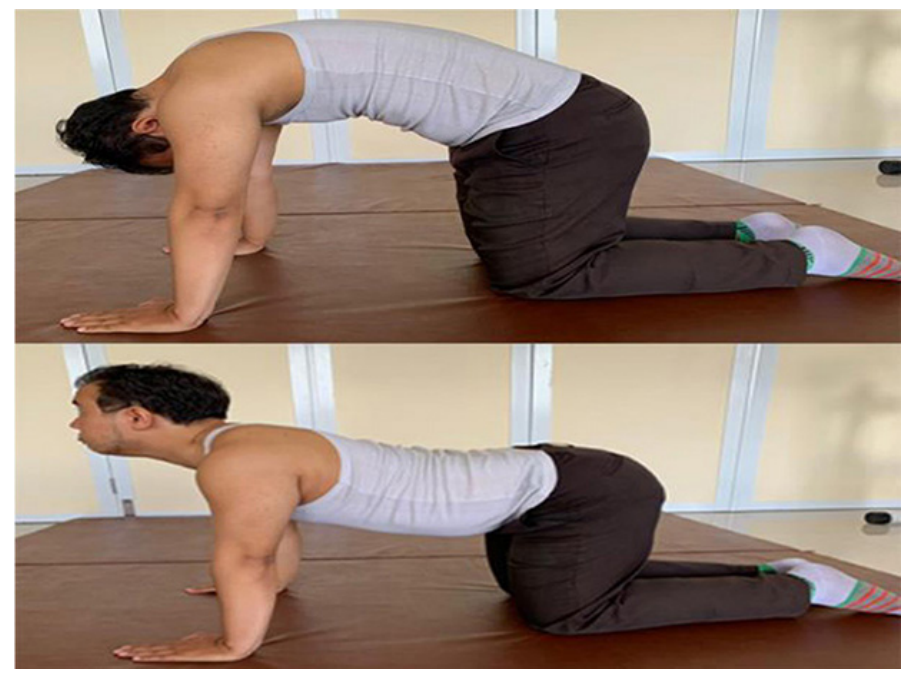

Figure 2. Cat \& camel exercise

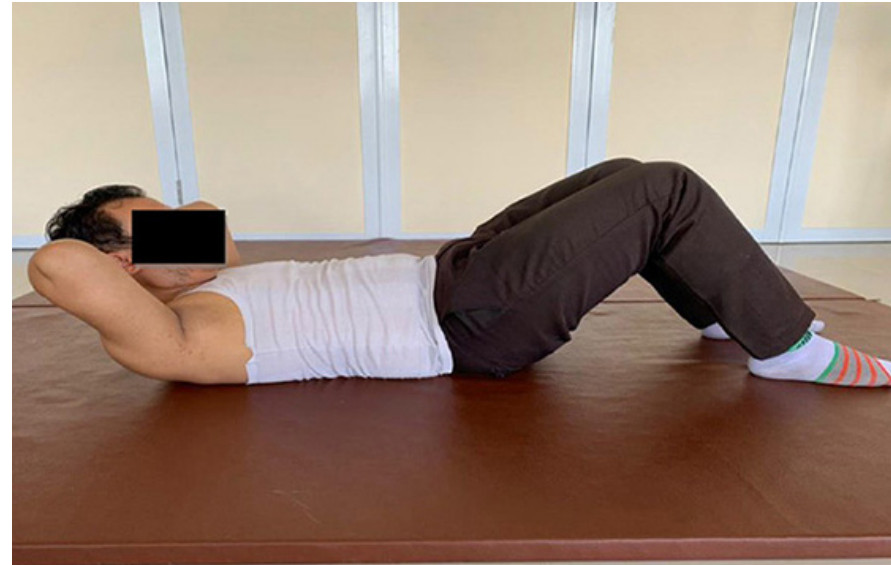

Figure 3. Slow curl up

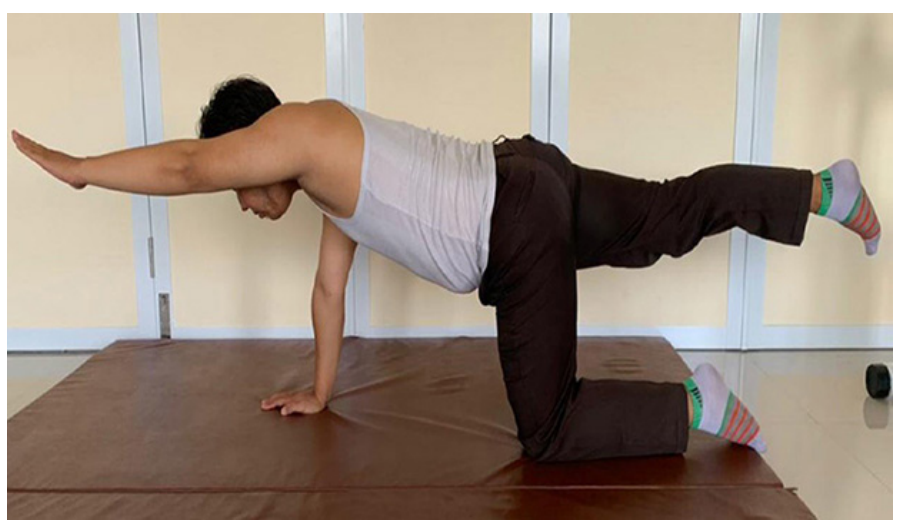

Figure 4. Bird dog exercise 
bending and lifting as usual. Pain decrease when resting in the supine position. The patient also had no previous history of fall and no bladder and bowel dysfunction.

The patient has visited a medical doctor and given the anti-inflammatory drugs. The patient takes it regularly according to the doctor's instructions. The patient also has visited physical therapy, and he reported that the physical therapist gives him heating modalities and stretching exercise. The patient has undergone an MRI examination, and the result was no dysfunction in disc structure and bones. The patient works as a roof tile craftsman demanding the patient to perform bending motion and lift the heavy loads (roof tile) every day. Patient past medical history such as high blood pressure, cholesterol, and diabetes history denied by the patient. The patient is a smoker and rarely does some exercise.

Physical therapy programs were given to the patient for an hour treatment session per day for three days during a two-weeks. The physical therapy program contained short wave diathermy (SWD), soft tissue mobilization, and core stability exercises (such as bridging, cat and camel, slow curl up, bird dog, raising head and shoulders off the ground with hands under the head, and superman (Figures 1-6)). The sequence of physical therapy program was: Firstly, given the thermal SWD for 20 mins and performed 10 mins of soft tissue mobilization to the iliopsoas, adductors, and quadratus lumborum muscles; Secondly, given core stability exercises, eight repetitions and two sets for each exercise (30 mins in total).

In the first week of evaluation, the patient reported his pain intensity was reduced but increased to the same level as on the first visit on the second week of evaluation. By then, a comprehensive reevaluation was performed by the physical therapist, which found the patient had non-ergonomic work habits (overloads and improper liftings). Therefore, the physical therapist gave the ergonomic intervention in addition to the physical therapy program three sessions per week during a five-weeks, including 15 mins stretching (Figure 7) (minimum 20s for four times reps to each stretching) and 15 mins lifting technique (Figure 8). 9 Moreover, the physical therapist informed the patient to use the assistive tools (such as trolley or chart trolley) to carry heavy loads.

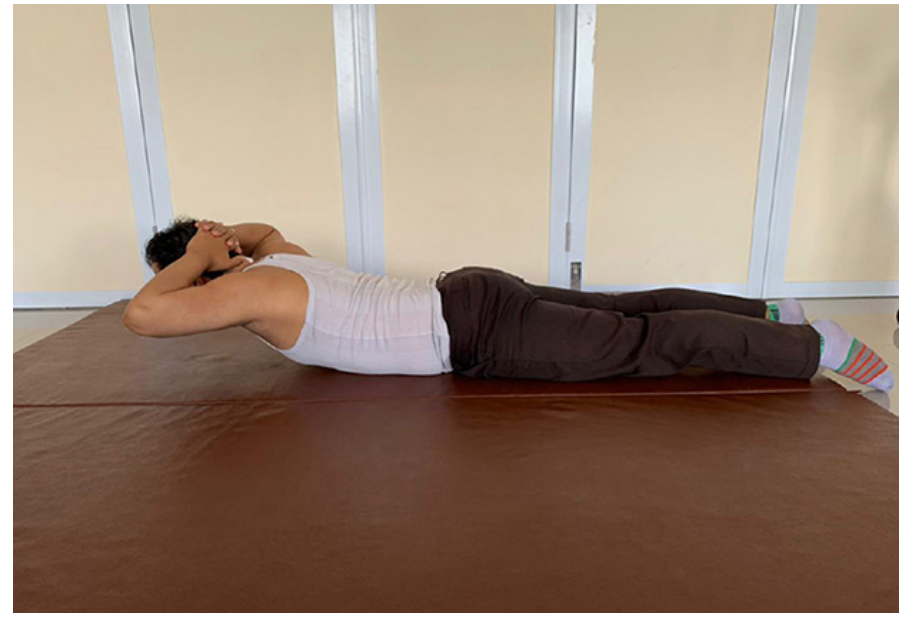

Figure 5. Raising head and shoulder off the ground

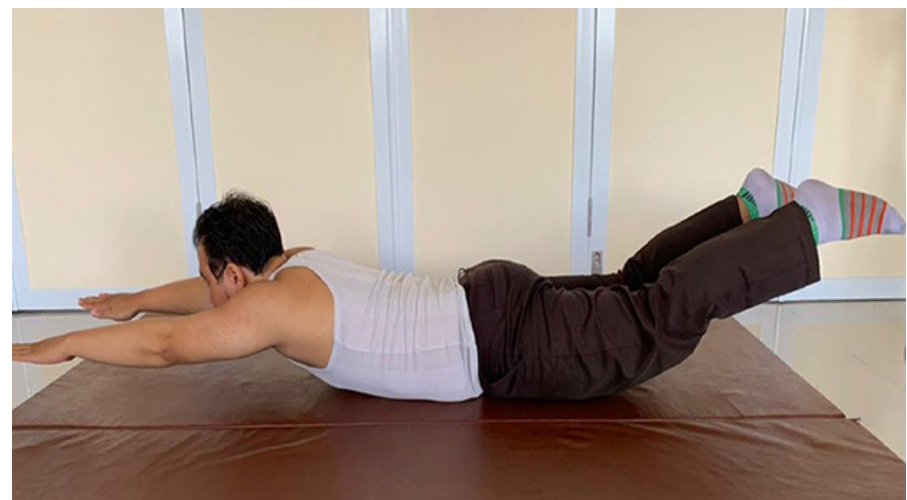

Figure 6. Superman

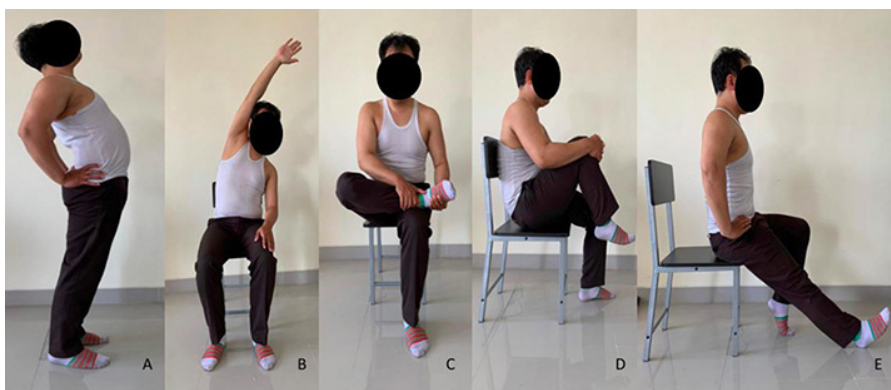

Figure 7. Stretching. A, standing back extension; B, sitting trunk lateral bending; C, sitting ankle on thigh; D, sitting knee to chest; E, sitting hamstring stretching

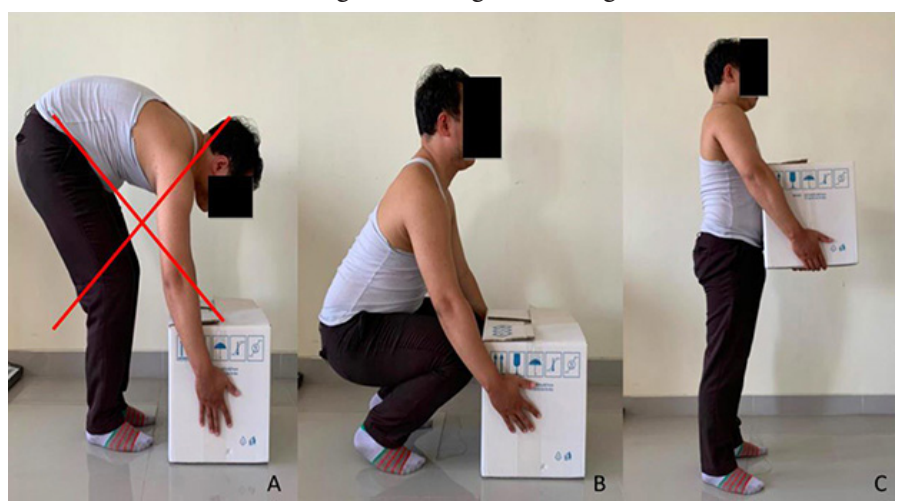

Figure 8. Lifting techniques. A, avoid lifting the heavy loads; B, when lifting the loads, avoid forward bending motion while lifting. Spine should be straight, knees doing squat and toes slightly outward. Use knee strength to lift the loads; C, when carrying the loads, do not put the loads over your head or higher than shoulder. The loads must be close to the body 
Table 1. Evaluation of visual analogue scale (VAS) and Modified Oswestry Disability Index (MODI) Score

\begin{tabular}{|c|c|c|c|c|c|c|c|c|c|}
\hline No. & Measurement & Baseline & $\begin{array}{c}\text { 1st } \\
\text { week }\end{array}$ & $\begin{array}{c}\text { 2nd } \\
\text { week }\end{array}$ & $\begin{array}{c}\text { 3rd } \\
\text { week }\end{array}$ & $\begin{array}{c}\text { 4th } \\
\text { week }\end{array}$ & $\begin{array}{c}\text { 5th } \\
\text { week }\end{array}$ & $\begin{array}{c}\text { 6th } \\
\text { week }\end{array}$ & $\begin{array}{c}\text { 7th } \\
\text { week }\end{array}$ \\
\hline 1 & Visual Analogue Scale (VAS) (0-10) & 6 & 5 & 6 & 5 & 3 & 2 & 1 & 0 \\
\hline 2 & $\begin{array}{l}\text { Modified Oswestry Disability Index (MODI) } \\
\text { Score (\%) }\end{array}$ & 60 & 46 & 40 & 28 & 20 & 12 & 4 & 0 \\
\hline
\end{tabular}

\section{EVALUATION}

The patient was given physical therapy programs like core stability exercise, soft tissue mobilization, and SWD added with ergonomic intervention. The examination results in a visual analogue scale used to measure pain intensity and a Modified Oswestry Disability Index to measure the level of disability.

Table 1 presents that the physical therapy program (SWD, soft tissue mobilization, and core stability exercises) decreased the pain from $6 / 10$ to $5 / 10$ in the first-week evaluation. However, in the second-week evaluation, the patient reported that the pain intensity increased to the same level as the baseline. After the additional ergonomic intervention, the patient reported the pain decreased gradually until the final evaluation felt no pain.

The patient's disability level constantly reduced from $60 \%$ to $0 \%$ during the seven-week intervention.

\section{DISCUSSION}

MLBP is a pain in the lower back caused by muscle disorders without radiating pain into the leg. ${ }^{10}$ MLBP usually occurs on roof tile craftsmen who use manual handling such as forward bending, lifting and carrying loads. Forward bending causes contraction on dorsal lumbosacral muscles and, if done repetitively, would increase muscle tension that caused pain. ${ }^{3}$

Roof tile craftsman often performs bending activity when lifting the loads repetitively. Forward bending motion will change the centre of gravity to the front, where the normal position of the centre of gravity lies on the centre line of the body around $2.5 \mathrm{~cm}$ in front of vertebrae sacral 2. Muscles in the lower back will work eccentrically, and the bodyweight pressure will be received by other tissues such as ligaments, discus and fascia. ${ }^{11}$ Change of the centre of gravity caused tenses up the ligament, and the muscle becomes contracted to maintain the normal posture. As a result, the lower back muscle will increase its tension and become spasm and will stimulate the nociceptor in the muscle. ${ }^{12}$ With increased nociceptor stimulation, the reflex of muscle tension will increase and resulting in local ischemia or inadequate microcirculation and deficit of oxygen and nutrients. ${ }^{11}$

Core stability exercise is an exercise aimed at the core muscle to maintain spine stability such as abdominal muscle, multifidus, traverse abdominis. ${ }^{13}$ The main target of this exercise is the muscle that lies deep from the stomach, which is connected to the spine. In the patient with MLBP, there is usually a disruption of control and activation in the deep muscle, which will activate global muscle excessively. When the core muscle is weak, muscle imbalance causes pain. ${ }^{14}$ Giving core stability exercise causes co-activation on deep trunk muscle so that balance of abdominal muscle and lumbar muscle on the back will form a better activation. Giving core stability exercise can overcome muscle imbalance in core muscle that balancing the contraction of agonist and antagonist muscles that decreased disability. ${ }^{15}$

Pain is one of many factors that cause the patient was unable to perform the activities. Soft tissue mobilization can provide a tension releasing effect in the fascia used to reduce symptoms of MLBP such as pain and muscle tightness. Soft tissue mobilization also improves venous return, the lymphatic system and the release of endogenous opioid that alleviate the pain. ${ }^{4}$

The patient was given SWD for 20 minutes for each visit. SWD can provide several mechanisms such as metabolic reaction; SWD can affect the given area. Chemical activity and metabolism in the cell will increase in temperature to $10 \mathrm{oC}$. High temperature in the tissue can increase the tissue's oxygen supply and nutrients to help the tissue healing process. ${ }^{16}$ The vascular effect of increased temperature on the tissue can also lead to vasodilatation. The sensory afferent system will receive and deliver information to the spinal cord and partially transmitted it to the branch of blood vessels in the skin resulting in the release of a vasoactive mediator like histamine and prostaglandin that can lead to vasodilatation. The neuromuscular effect, heat intervention will produce the analgesic effect and reduce pain intensity. ${ }^{17}$

The physical therapist gave the ergonomic intervention to the patient because he did not know how to work with the right body posture. The patient directed to perform the right posture 
actively to prevent excessive loading to the spine and reduce symptoms of MLBP. Ergonomic intervention is useful for reducing the loads received by the spine during activity, preventing recurrent musculoskeletal pain, and elevating the healing process of the injured muscles. ${ }^{18}$ To move the body pain-free while lifting the loads, the patient should keep the spine straight from the pelvic to the head. ${ }^{19}$ This body posture should be remembered and practiced by the patient when he works.

\section{CONCLUSION}

In this case study, we conclude that ergonomic intervention combined with physical therapy programs effectively decreased pain and improved functional activity on the subject with MLBP.

\section{CONFLICT OF INTEREST}

There is no conflict of interest.

\section{FUNDING}

$\mathrm{N} / \mathrm{A}$

\section{AUTHOR CONTRIBUTIONS}

IMDP conceived the study design, collected the case information, and drafted the manuscript; IAAS and KTAS drafted the manuscript.

\section{REFFERENCE}

1. Delitto A, George SZ, Van Dillen L, Whitman JM, Sowa G, Shekelle P, et al. Low back pain. J Orthop Sports Phys Ther. 2012;42(4):A1-57.

2. Patel C, Babu VK, Kumar SN, Asha D. Effect of Hip Mobilization with Exercises for Subjects with Chronic Non Specific Low Back Pain Associated with Hip Impairment. INTERNATIONAL JOURNAL OF PHYSIOTHERAPY. 2015;2(1):376-85.

3. Agustina A, Camelia A, Hasyim H. Physical and Occupational Risk Factors Towards Complaints of Low Back Pain on Tile Maker Workers in Gedung Rejo Village Bk. 9 Oku Timur. Jurnal Ilmu Kesehatan Masyarakat. 2014;5(2):154-61.

4. Antony LAP, Iyer LS. Effectiveness of integrated soft tissue mobilization on the functional outcome in chronic low back pain patients. Journal of Exercise Science and Physiotherapy. 2013;9(1):57.
5. Pillastrini P, Mugnai R, Bertozzi L, Costi S, Curti $\mathrm{S}$, Guccione A, et al. Effectiveness of an ergonomic intervention on work-related posture and low back pain in video display terminal operators: a 3 year cross-over trial. Appl Ergon. 2010;41(3):436-43.

6. Punnett L, Bergqvist U. Visual display unit work and upper extremity musculoskeletal disorders. Stockholm: National Institute for Working Life. 1997;997.

7. Brewer S, Van Eerd D, Amick Iii BC, Irvin E, Daum $\mathrm{KM}$, Gerr F, et al. Workplace interventions to prevent musculoskeletal and visual symptoms and disorders among computer users: a systematic review. Journal of occupational rehabilitation. 2006;16(3):317.

8. Verhagen AP, Karels CC, Bierma-Zeinstra SM, Burdorf LL, Feleus A, Dahaghin SS, et al. Ergonomic and physiotherapeutic interventions for treating work-related complaints of the arm, neck or shoulder in adults. Cochrane database of systematic reviews. 2006(3).

9. Parekh S, Mehta E. Effectiveness of Ergonomic Advice and Physiotherapy Intervention in Indian Nurses with Low Back Pain. International Journal of Recent Scientific Research. 2015;6(9):6255-9.

10. Basuki K. Faktor risiko kejadian low back pain pada operator tambang sebuah perusahaan tambang nickel di sulawesi selatan. Jurnal Promosi Kesehatan Indonesia. 2009;4(2):115-21.

11. Page P, Frank C, Lardner R. Assessment and treatment of muscle imbalance: the Janda approach. Journal of orthopedic \& sports physical therapy. 2011;41(10):799-800.

12. Xu Y-M, Ge H-Y, Arendt-Nielsen L. Sustained nociceptive mechanical stimulation of latent myofascial trigger point induces central sensitization in healthy subjects. The Journal of Pain. 2010;11(12):1348-55.

13. Stuber KJ, Bruno P, Sajko S, Hayden JA. Core stability exercises for low back pain in athletes: a systematic review of the literature. Clin J Sport Med. 2014;24(6):448-56.

14. Akuthota V, Ferreiro A, Moore T, Fredericson M. Core stability exercise principles. Curr Sports Med Rep. 2008;7(1):39-44.

15. Panjabi MM. The stabilizing system of the spine. Part II. Neutral zone and instability hypothesis. J Spinal Disord. 1992;5:390-.

16. Prentice WE. Therapeutic modalities for physical therapists. 2002.

17. Bellew JW, Michlovitz SL, Nolan Jr TP. Michlovitz's modalities for therapeutic intervention: FA Davis; 2016.

18. Ribeiro L, Jennings F, Jones A, Furtado R, Natour J. Effectiveness of a back school program in low back pain. Clin Exp Rheumatol. 2008;26(1):81.

19. Jaromi M, Nemeth A, Kranicz J, Laczko T, Betlehem J. Treatment and ergonomics training of work-related lower back pain and body posture problems for nurses. J Clin Nurs. 2012;21(11-12):1776-84.

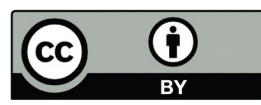

This work is licensed under a Creative Commons Attribution 